\title{
MITOS GENDHING DALAM UPACARA BERSIH DUSUNDALUNGAN, KELURAHAN MACANAN, KECAMATAN KEBAKKRAMAT, KABUPATEN KARANGANYAR
}

\author{
Ita Puspita Dewi \\ Pengajar di Rhythm Star Music School \\ Email: gorgpuspita@gmail.com |0857-2614-2704
}

\begin{abstract}
This paper, entitled "Gendhing Myth in the Bersih Dusun Ceremony in Dalungan, Macanan, Kebakkramat, Karanganyar" started from the writer's interest in seeing the socio-cultural phenomenon that has become an annual tradition for Dalungan Hamlet residents. This study aims to uncover the gendhing posted by the community in the bersih dusun ceremony of the Dalungan hamlet. The myth of Gendhing is inseparable from the factors that influence the existence of sacred values related to the rite. The magical value that exists in the Gendhing is based on the cultural belief system of Javanese actors and other supporting elements of ritual such as folklore and cultural values inherited from the ancestors. The myth of Gendhing must also be supported by the presence of dhanyang and also the pundhèn caretaker, as well as community leaders such as the $R W$ leader, RT leader, Dalungan elders, and the entire Dalungan community. This research uses qualitative research methods, including observation, data collection, data analysis, data presentation, and conclusions. This research uses P.S Hary Susanto's myth theory which explains the myths according to Mercia Eliade's thought, which is to solve problems related to the myths of Javanese cultural society and the myth of Gendhing in the clean ritual of the Dalungan hamlet.
\end{abstract}

Keywords: myth, compulsory gendhing, bersih dusun.

\section{Pendahuluan}

Masyarakat Dalungan adalah komunitas petani pedesaan Jawa yang masih percaya dengan pertanda atau kejadian-kejadian di alam sekitar yang berhubungan dengan perkara gaib. Masyarakat Dalungan juga percaya adanya mitos yang tersebar di masyarakat sejak jaman dulu dan membekas hingga sekarang melalui cerita sebagai sebuah ajaran dalam bermasyarakat, sehingga mitos tersebut dapat mempengaruhi pola pikir manusia dalam tatanan kehidupan. Hal itu menandakan bahwa mitos merupakan produk perjalanan budaya yang unik, diceritakan dan dilambangkan dengan benda atau simbol-simbolyang menghadirkan pesan atau makna yang berkaitan dengan aturan masa lalu, ide, ingatan serta kenangan (lihat Barthes 1981: 193; Kasanova and Widjajanti 2018: 104; Hasanudin dalam Kasanova and Widjajanti 2018: 104).

Mitos bukan hanya sekedar cerita yang dikisahkan, namun juga merupakan kenyataan yang dihayati hingga memiliki daya untuk membangkitkan loyalitas yang seragam pada sebuah masyarakat (Malinowski 1979: 101; Anderson 2008: 10). Kumpulan mitos yang ada di Jawa seringkali dihubungkan dengan adanya prosesi-prosesi sakral, mulai dari kelahiran, pernikahan, dan kematian. Bahkan, beberapa aktivitas yang berhubungan dengan ritual keagamaan masih sering dikaitkan dengan adanya mitos, seperti halnya pada upacara bersih dusun atau upacara hari besar lainnya yang melibatkan sebuah ritual. Pada umumnya, mitos seringkali dihubungkan dengan sarana dan prasarana yang bersifat gaib, bersifat tidak nyata atau tidak 
dapat dibuktikan secara kasat mata. Di sinilah manusia cenderung mengacu pada mitos sebagai seperangkat simbol sekaligus abstraksi pengalaman di masa lampau, untuk mengklasifikasikan dan menertibkan fenomena yang ada di alam pikirannya (lihat Iswidayanti 2007: 180-181; Yulia and Okwita 2017: 381).

Kepercayaan terhadap sesuatu yang bersifat gaib, atau tidak dapat dibuktikan secara kasat mata yang dalam dalam pengertian lain juga disebut takhayul atau folk belief (lihat Danandjaya 1986: 153) telah menjadi budaya kebanyakan orang Jawa dalam kaitannya menghayati kepercayaan terhadap Tuhan Yang Maha Esa. Takhayul dalamhal ini dapat dimaknai sebagai sarana pengajaran untuk mengingatkan manusia terhadap hal-hal yang tidak dapat dibuktikan secara akal, namun berkaitan erat dengan bangunan keselarasan hubungan hidup manusia, alam gaib, dan alam semesta dan dunia seperti yang dijelaskan oleh Uniawati (2012: 4). Di kalangan masyarakat Jawa, terdapat peringatan agar 'tidak melupakan asal'. Peringatan tersebut mengharuskan masyarakat Jawa memiliki sikap eling kepada Sang Pencipta, waspada terhadap apa yang dilakukan dan yang belum terjadi, percaya akan adanya kekuasaan Tuhan dan yang diciptakan baik yang nyata maupun tak kasat mata, serta mituhu atau selalu mengikuti peraturan. Begitulah masyarakat Jawa kebanyakan dalam memperlakukan mitos dalam orientasi kehidupan yang telah diyakini.

Masyarakat Dalungan sendiri masih banyak mempercayai makhluk-makhluk yang biasanya disebut dhanyang. Salah satunya teraktualisasikan melalui upacara bersih dusun, yaitu upacara adat atau tradisi dalam masyarakat yang diselenggarakan untuk membersihkan dusun dari gangguan-gangguan makhluk gaib yang dapat mengakibatkan malapetaka dan marabahaya, serta memohon keselamatan dan ketentraman hidup melalui berbagai prosesi ritual yang melibatkan pemberian sesaji kepada dhanyang. Pusat dari segala terjadinya mitos yang ada pada upacara bersih dusun Dalungan terletak pada kekuasaan dhanyang tersebut. Hal tersebut mempengaruhi adanya mitos tentang gendhing-gendhing khusus yang diwajibkan saat prosesi upacara berlangsung. Melalui sebuah ritus tertentu, mitos-mitos tentang dewa-dewa atau makhluk-makhluk ilahi terus ada dan diyakini oleh masyarakat pemilik kebudayaan tersebut. Hal itu menunjukkan bahwa ritual dan upacara desa memainkan peran penting dalam melestarikan sistem keagamaan lama, termasuk bentuk-bentuk tradisi lainnya seperti musik, tarian, dan/atau teater yang menjadi prasyarat penting dan terkait langsung di dalamnya (Nicolas 2019: 55).

Sejarah terjadinya upacara bersih dusun Dalungan berkaitan erat dengan cerita rakyat tentang Kyai Jaka Dholog yang dipercaya sebagai dhanyang setempat (lihat Wibowo 2018: 2). Cerita rakyat tersebut diwariskan secara lisan dari generasi ke generasi, serta diyakini kebenarannya oleh masyarakat Dalungan. Cerita tersebut bermula ketika sebuah daerah kecil yang memiliki tanah gersang dan tandus didatangi oleh sosok misterius bernama Kyai Jaka Dholog yang merupakan patih dari Pakubuwono V. Tanah gersang dan tandus menyebabkan penduduk tergolong miskin, karena selalu gagal ketika bertani. Kedatangan Kyai Jaka Dholog bermaksud untuk melakukan semedi (bertapa) di sebuah candi peninggalan Hindu, berupa artefak kecil berbentuk yoni. Setelah Kyai Jaka Dholog melakukan semedi beberapa waktu, taraf kehidupan masyarakat semakin membaik. Namun tak lama kemudian, tepatnya pada hari Jumat Legi, Kyai Joko Dholog menghilang dan diduga masuk ke dalam candi.

Cerita selanjutnya (lihat Wibowo 2018: 37), kemudian pada abad ke-17 hiduplah seorang sesepuh yang dihormati bernama Suwarso. Saat melakukan puasa ngebleng (penuh) selama satu hari satu malam, di dalam mimpinya, Suwarso didatangi sesosok lelaki memakai baju warna hitam, bercelana hitam, memakai ikat gadhung mlathi, dan membawa galungan kendi berisi air. Sosok lelaki tersebut adalah Kyai Jaka Dholog sebagai penguasa dan penjaga daerah tersebut. Kyai Jaka Dholog memberi petunjuk kepada Suwarso, bahwa jika penduduk ingin tanahnya menjadi subur dan sejahtera, berilah daerah tersebut dengan nama 
"Galungan". Kata galungan memiliki makna bahwa tanah tersebut subur dan kaya air seperti galungan yang selalu dibawa oleh Kyai Jaka Dholog, sehingga penduduk setempat yang disepuhi Suwarso, memberi nama pada daerah tersebut dukuh Galungan. Lambat laun, dukuh Galungan berubah nama dengan sendirinya menjadi "Dukuh Dalungan", karena ucapan dari mulut ke mulut sehingga mengalami perubahan huruf depan.

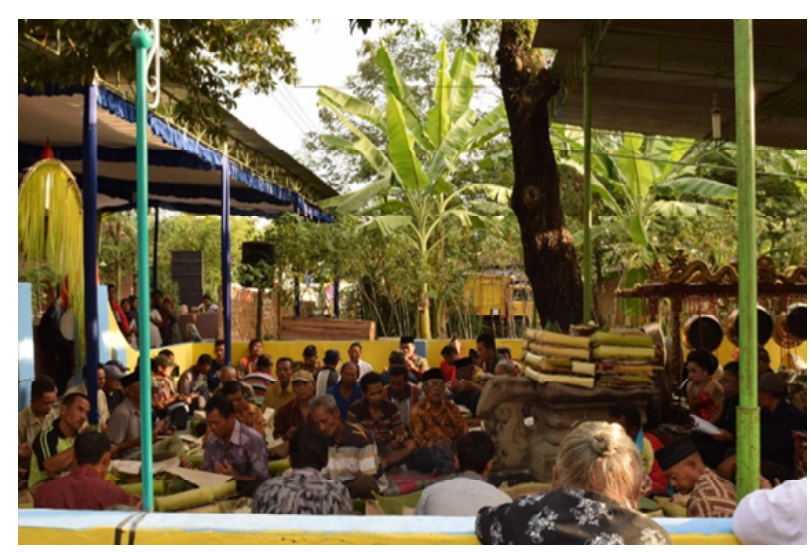

Gambar 1. Prosesi doa dalam upacara bersih dusun Dalungan di pundhèn (foto oleh Ita Puspita Dewi, 2017)

Pelaksanaan bersih dusun Dalungan yang di dalamnya terdapat prosesi doa seperti yang ditunjukkan pada gambar 1, dilakukan pada hari Jumat legi, berkaitan dengan hari saat Kyai Jaka Dholog menghilang. Hari Jumat dan pasaran Jawa Legi dalam pelaksanaan bersih dusun dianggap paling baik untuk berkomunikasi dengan leluhur. Hal ini mengandung makna, bahwa hari tersebut membawa berkah bagi masyarakat dukuh Dalungan. Menurut pemikiran Susanto (1987: 61), manusia tidak mampu mendekati Yang Kudus secara langsung, karena Yang Kudus itu transenden, sedangkan manusia adalah makhuk temporal yang terikat di dalam dunianya. Dengan demikian, manusia dapat mengenal Yang Kudus yaitu melalui simbol. Simbol merupakan suatu cara untuk dapat sampai pada pengenalan akan Yang Kudus dan yang transenden. Semua yang dilakukan oleh manusia pada umumnya melibatkan simbol. Hal tersebut menandakan bahwa setiap ritus dilakukan dengan melibatkan berbagai sarana simbol-simbol, begitu juga dengan adanya mitos.
Upacara ritual bersih dusun di dukuh Dalungan diselenggarakan berdasarkan hati nurani yang tulus dari warga masyarakat, untuk meneruskan tradisi yang telah berjalan secara turun-temurun dari nenek moyang sebagai bentuk hierofani. Sejalan dengan pemikiran Susanto (1987: 196), hierofani merupakan sasaran penting penghayat kepercayaan dalam menjalankan bersih dusun, agar dapat mencapai kesucian. Kesucian berarti tanda-tanda akan datangnya keselamatan hidup. Tujuan utama dari proses hierofani tidak hanya formalitas ritual tahunan, namun memiliki bobot spiritual yang luar biasa. Unsur-unsur mitos yang terkandung di dalamnya sangat kuat dan berperan akan adanya upacara tersebut. Ritual bersih dusun menjadi sebuah wahana untuk; (1) menyatukan rasa syukur kepada Tuhan Yang Maha Esa atas ketentraman penduduk dusun, (2) memberi penghormatan pada roh leluhur atau cikal bakal dusun, dan (3) mengharap pengayoman dari Tuhan Yang Maha Esa agar panen yang akan datang lebih meningkat dan taraf hidup masyarakat dusun lebih sejahtera (lihat juga Wibowo 2018: 35).

\section{Mitos-Mitos dalam Ritual Bersih Dusun Dalungan}

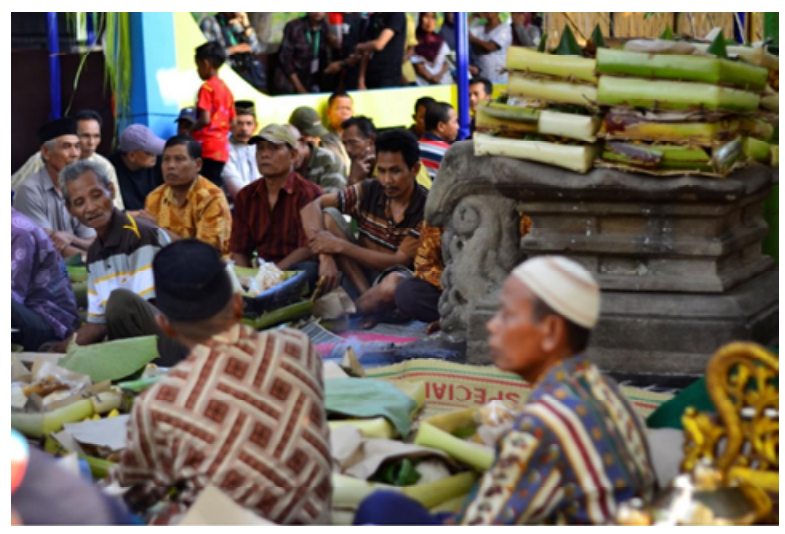

Gambar 2. Prosesi kenduri bersih dusun di halaman artefak berupa candi berbentuk Yoni (foto oleh Muhamad Aji Kuncoro, 2017)

Masyarakat Dusun Dalungan melaksanakan upacara ritual bersih dusun melalui prosesi kenduri seperti yang ditunjukkan pada gambar 2 di halaman candi (pundhèn) peninggalan zaman Hindu yang 
dinamakan candi yoni. Mitos tentang pundhèn (tempat yang dianggap suci dan sakral) bagi masyarakat Dalungan tampaknya sudah mengakar dan sangat mempengaruhi tingkah laku kehidupan masyarakat pendukungnya. Menurut Marto Samiyun (wawancara 20 Desember 2018), juru kunci pundhèn, artefak yang diyakini memiliki nilai magis ini sudah ada sejak lama, dan hingga sekarang belum dapat dipastikan usianya. Artefak ini berbentuk segi empat, berupa candi kecil yang menyerupai bentuk yoni (alat kelamin perempuan), dengan panjang 1,3 meter dan lebar 1 meter. Di sisi depan bagian bawah terdapat relief menyerupai bentuk anak kecil. Artefak tersebut diidentifikasi sebagai simbol kesuburan.

Sejarah kemunculan artefak tersebut tidak ada yang mengetahui pasti ceritanya. Masyarakat mempercayai candi yoni sebagai jelmaan Kyai Jaka Dholog yang menghilang pada saat ber-semedi. Menurut Sukino (Wawancara, 20 Desember 2018), warga Dusun Dalungan, konon artefak tersebut datang sendiri, pernah dipindahkan di Dusun Nayan dan Dusun Nangsri (dusun sebelah barat Dusun Dalungan), namun kembali lagi; dari situ masyarakat mempercayai bahwa artefak tersebut diturunkan oleh Sang Pencipta untuk melindungi Dusun Dalungan beserta warga masyarakatnya.

Menurut Marto Samiyun (wawancara 20 Desember 2018), terdapat 3 dhanyang yang diyakini terdapat pada pundhèn tersebut, diantaranya adalah Kyai Jagadala, Kyai Panjipra, dan Kyai Gendongali. Ketiga nama tersebut menjadi sebutan untuk dhanyang bagi masyarakat yang mempercayainya, dan juga bagi mereka yang sering berdoa meminta suatu hal kepada Sang Pencipta melalui pundhèn tersebut. Tak banyak orang yang mengetahui sejarah adanya dhanyang yang menunggu pundhèn tersebut, namun masyarakat setempat meyakini dhanyang tersebut sebagai cikal bakal terbentuknya Dusun Dalungan.

Kepercayaan masyarakat terhadap mitosmitos dhanyang pada pundhèn turut mempengaruhi kepercayaan masyarakat terhadap kekuatan mitos pada gendhing-gendhing yang disajikan dalam upacara bersih dusun. Kenyataan tersebut tampak seperti penjelasan Susanto (1987: 76) mengenai asal-usul mitos, disebutkan bahwa mitos mengisahkan bagaimana suatu realitas itu muncul dan bereksistensi, serta bagaimana manusia harus hidup dalam masyarakat dengan tata tertib dan normanorma tertentu. Asal-usul sebuah tempat yang dianggap sakral, dalam hal ini pundhèn Dalungan, membentuk peraturan-peraturan baru yang dimitoskan, seperti mitos yang terkandung dalam gendhing yang berkaitan erat pada pundhèn tersebut.

Masyarakat berdoa melalui pundhèn, dhanyang, dan sesajèn kepada Tuhannya. Seperti yang telah dijelaskan oleh Susanto, apabila sebuah pohon atau batu menjadi objek pemujaan, sebenarnya orang tidak menyembah pohon belaka, atau hanya menyembah batu melulu. Orang menyembah pohon atau batu itu sebagai bentuk hierofani. Pohon atau batu yang disembah itu merupakan perwujudan dari Yang Kudus. Dengan hadirnya Sang Kudus, setiap benda menjadi sesuatu yang lain walaupun benda itu tetap tampak seperti bendanya (Susanto 1987: 62).

Beberapa orang percaya bahwa mitos merupakan hasil personifikasi dan kekuatan benda mati. Begitu pula pada upacara bersih dusun Dalungan, segala bentuk mitos didasari atas adanya pundhèn yang dianggap sebagai tempat sakral oleh masyarakat pemilik budaya. Pundhèn tersebut diyakini memiliki kekuatan besar atas keselamatan dusun, bahwa tempat itulah yang melindungi dusun dari segala macam bahaya. Hal ini tentunya atas kehendak dan kuasa Tuhan Yang Maha Esa.

\section{Gendhing dalam Bersih Dusun Dalungan}

Gendhing merupakan istilah yang digunakan masyarakat karawitan Jawa, Bali, Sunda, dan beberapa daerah lain di Indonesia untuk menyebutkan bentuk komposisi musikal karawitan yang menyajikan seni suara, baik instrumental maupun vokal atau gabungan dari keduanya. Martopengrawit (1975: 3) menyebut gendhing sebagai susunan nada yang telah memiliki bentuk, sedangkan Supanggah (2007: 70) mengartikan 
gendhing sebagai sesuatu yang lebih kompleks dari sekedar urusan susunan nada dan bentuk. Gendhing merupakan salah satu istilah yang sangat penting di dalam karawitan dan gamelan. Istilah ini digunakan untuk memberi nama lagu-lagu nyang disajikan oleh gamelan baik secara instrumental saja maupun dengan vokal, dan di dalam gendhing inilah terutama konsep pathet beroperasi (Hastanto 2009: 47-48).

Di dalam karawitan, istilah gendhing bisa diartikan sebagai lagu yang memiliki bentuk dan struktur tertentu. Menurut Rusdiyantoro (Wawancara 3 Juli 2019), gendhing dapat diartikan hanya sebagai instrumentalia saja, namun untuk karawitan di Jawa Tengah khususnya, gendhing dapat berupa instrumentalia beserta vokalianya. Gendhing itu lebih dahulu ada, kemudian vokalisnya masuk atau mengikuti. Hal tersebut juga dijelaskan dalam Serat Centhini yang berbunyi "gendhing muni tinabuh kalawan tangan", artinya gendhing tersebut berbunyi ketika sudah ditabuh dengan tangan.

Supanggah (2007: 104) menjelaskan bahwa gendhing juga dapat dikategorikan menurut ukurannya, serta dibedakan menjadi tiga kategori.

a. Gendhing Ageng, biasanya ditandai dengan durasi gendhing yang relatif panjang. Gendhing ini biasanya ditandai dengan istilah Kethuk Kerep dan Kethuk Arang. Kerep berarti 'kerap' dan arang berarti 'jarang'. Bentuk gendhing yang termasuk dalam kategori Gendhing Ageng yaitu Gendhing Kethuk 4 Awis dan Kethuk 8 atau 4 Kerep.

b. Gendhing Tengah atau Sedheng (sedang), biasanya ditandai dengan durasi yang tidak terlalu pendek maupun panjang. Bentuk gendhing yang termasuk dalam kategori Gendhing Tengah yaitu gendhing-gendhing Kethuk 2 Kerep.

c. Gendhing Alit, biasanya ditandai dengan penulisan judul gendhing yang tidak menyertakan kata "gendhing" di dalamnya. Gendhing ini biasanya memiliki durasi yang pendek. Bentuk dan struktur yang termasuk dalam kategori Gendhing Alit yaitu Lancaran, Ketawang, dan Ladrang.
Menurut ukurannya, gendhing-gendhing wajib yang ada pada upacara bersih dusun Dalungan termasuk di dalam kategori Gendhing Tengahan dan Gendhing Alit. Ladrang Wilujeng Laras Sléndro Pathet Manyura dan Ladrang Éling-éling Laras Sléndro Pathet Manyura termasuk di dalam kategori Gendhing Alit karena memiliki struktur dan bentuk gendhing berupa Ladrang, sedangkan Gambirsawit Gendhing Kethuk 2 Kerep Inggah 4 Laras Sléndro Pathet Sanga termasuk dalam kategori Gendhing Tengahan karena bentuk dan strukturnya berupa Kethuk 2 Kerep. Berikut adalah contoh penyebutan bentuk gendhing dalam karawitan gaya Surakarta.

\begin{tabular}{|cc|c|c|}
\hline $\begin{array}{c}\text { Bentuk } \\
\text { Gendhing }\end{array}$ & Nama Gendhing & Jenis Laras & Jenis Pathet \\
\hline Ketawang & Subakastawa & Pélog & Barang \\
\hline
\end{tabular}

Tabel 1. Contoh penyebutan bentuk gendhing

"Ladrang" menjadi sebutan untuk bentuk gendhing, "Wilujeng" merupakan nama gendhing, "Laras Pélog" adalah Laras gamelan yang digunakan untuk menyajikan gendhing tersebut, sedangkan "Pathet Barang" merupakan wilayah nada yang digunakan dalam menyajikan gendhing pada gamelan.

Dalam ritual bersih dusun, gendhing biasanya disajikan sebagai pertunjukan untuk sarana hiburan atau iringan pertunjukan lain. Namun, lain halnya dengan dusun Dalungan, yang memiliki gendhing wajib dalam ritual bersih dusun. Biasanya, masyarakat penghayat kepercayaan menyajikan gendhing wajib saat upacara berlangsung. Terdapat tiga gendhing wajib yang selalu disajikan, yakni Ladrang Wilujeng Laras Sléndro Pathet Manyura, Ladrang Éling-éling Laras Sléndro Pathet Manyura, dan Gendhing Gambirsawit Laras Sléndro Pathet Sanga. Gendhing-gendhing tersebut merupakan gendhing umum yang biasa disajikan dalam pementasan karawitan yang biasanya disebut dengan klenèngan gaya Surakarta.

Ketiga gendhing wajib tersebut merupakan gendhing-gendhing yang sangat populer, namun hal 
itu menjadi menarik karena masyarakat Dusun Dalungan mempercayai adanya mitos pada ketiga gendhing tersebut. Masyarakat Dalungan justru memaknai gendhing-gendhing tersebut menjadi hal yang sakral dan diwajibkan untuk keperluan sarana ritual bersih dusun, sehingga gendhing-gendhing tersebut dianggap suci dan agung. Kepercayaan terhadap mitos menjadikan bentuk-bentuk gendhing tradisional karawitan tetap terawat dan terjaga keasliannya dengan bentuk dan struktur yang konvensional dan baku (pakem), agak berbeda dengan kasus-kasus pelestarian lainnya yang cenderung ditempuh melalui proses inovasi atau pembaruan yang signifikan (lihat Wahyudi 2018: 42; Kiswanto dkk 2019: 12).

Masyarakat Dalungan percaya akan adanya kekuatan pada ketiga gendhing wajib tersebut, yang dapat memberikan kesejahteraan bagi kehidupan masyarakat Dalungan. Meskipun demikian, cerita yang ada dibalik gendhing-gendhing tersebut adalah hal-hal buruk yang dapat menimpa masyarakat Dalungan jika ketiga gendhing wajib tersebut tidak dimainkan dalam bersih dusun. Hal tersebut tidak lepas dari keberadaan pundhèn yang menjadi pusat atau sumber kekuatan. Masyarakat Dalungan percaya bahwa Yang Kudus adalah yang sungguhsungguh nyata, menjadi sumber kekuatan dan semua energi. Dalam upacara tersebut, sesuatu yang bersifat magis dapat menjadi sesuatu yang agung, namun juga dapat menakutkan sebagai penyebab hidup dan mati.

Samiyun sebagai juru kunci pundhèn menjelaskan bahwa "kono kuwi ampuh (dhanyangé), kudu dituruti apa penjalukane lan apa kesenangané. Nèk senengané tayub ya kudu ènèk, Wilujeng, Éling-éling, Gambirsawit ya kudu diunèkné, merga kuwi kesenengané telu mau," yang berarti "dhanyang tersebut sangat kuat, harus dituruti apapun yang diinginkan. Jika suka dengan kesenian tayub ya harus ada, Ladrang Wilujeng, Ladrang Éling-éling, dan Gendhing Gambirsawit ya harus dibunyikan, karena itu adalah kesukaan ketiga dhanyang tersebut" (wawancara 14 Februari 2019).
Masyarakat Dalungan juga menceritakan gendhing berdasarkan judul serta cakepan atau teks musikal. Teks musikal dan judul ketiga gendhing tersebut merupakan doa dari hasil orientasi spiritual masyarakat setempat. Masyarakat Dalungan percaya bahwa teks musikal ketiga gendhing tersebut berkaitan dengan perilaku dan menjadi sebuah pengajaran yang ditunjukan kepada seluruh pelaku tradisi. Hal tersebut dapat dilihat dari bentuk dan makna dari teks musikal masing-masing gendhing.

\section{Ladrang Wilujeng Laras Sléndro Pathet Manyura}

"Ladrang Wilujeng" adalah salah satu gendhing yang usianya relatif muda. Ladrang ini diciptakan pada masa Patih Sasradiningrat IV pada kurun tahun 1889-1910, tepatnya di Kepatihan Surakarta. Sebagai salah satu gendhing yang populer di kalangan masyarakat Jawa, Ladrang Wilujeng umumnya dimainkan sebagai sebuah ungkapan doa untuk meminta keselamatan (Rusdiyantoro, wawancara 3 Juli 2019). Hal tersebut sesuai dengan terminologinya yang berarti 'keselamatan'. Oleh karena itu, secara logis, syair teks di dalamnya selayaknya berisi permohonan keselamatan pula. Ladrang Wilujeng juga termasuk sebagai Gendhing Gérong, jenis tembang-nya adalah Salisir. Khusus dalam upacara bersih dusun Dalungan, Ladrang Wilujeng disajikan dengan Laras Slendro Pathet Manyura dengan gerongan Salisir Puspagiwang dengan cakepan dan terjemahan bebas sebagai berikut.

(1) Parabé Sang 'Smarabangun, sepat domba Kali Oya, aja dolan lan wong priya, nggeramèh nora prasaja. (2) Garwa Sang Sindura Prabu, wicara mawa karana, aja dolan lan wanita, tan nyata asring katarka. (3) Sembung langu munggwing gunung, kunir wisma kembang rekta, aja ngguyu ujarira, wong lanang sok asring cidra.

(1) Dialah Sang Asmarabangun, ikan sepat besar dari Sungai Oya, jangan bermain-main dengan pria, jika tidak ingin diremehkan 
karena sesuatu yang ditutupi; (2) Isteri Prabu Sindura, berbicara dengan berteka-teki, jangan bermain dengan wanita, karena tidak bisa diterka maksud yang sebenarnya; (3) Tanaman sambung yang berada di pegunungan, kunyit yang ditanam di pekarangan rumah dengan bunganya yang berwarna merah, jangan mengikuti ucapannya, karena para lelaki sering ingkar janji.

Teks musikal diatas berisi tentang petuah hidup berkeluarga dan bermasyarakat; untuk selalu waspada terhadap godaan dunia; untuk tidak selalu merasa unggul, karena kehancuran seseorang hanyalah karena mulut dan tindakannya; serta untuk menjaga hati dan selalu berada di jalan yang lurus, sebab harga diri dalam bermasyarakat bisa hancur karena kesalahan orang yang sering ingkar janji.

Dari kutipan lagu di atas, tampak bahwa tidak satu kata pun yang secara eksplisit mengandung pengertian tentang keselamatan. Menurut Rusdiyantoro (wawancara 3 Juli 2019), isi dari teks di atas adalah kondisi sosial di tahun 1880 -an yang menyatakan bahwa jangan pergi dengan laki-laki yang bukan saudara, jangan pergi dengan perempuan yang bukan saudara, jangan pergi ke sana, jangan berbuat bohong; pada intinya tentang larangan-larangan yang harus dijauhi demi keselamatan masing-masing. Teks tersebut juga diambil dari "Ketawang Puspagiwang" yang teksnya cukup populer pada zaman itu.

Selain menjadi salah satu gendhing wajib dalam ritual bersih dusun Dalungan, Ladrang Wilujeng juga sering disajikan dalam rangkaian upacara Tingalan Jumenengan di Keraton Kasunanan Surakarta. Dalam upacara tersebut, Ladrang Wilujeng merupakan gendhing doa keselamatan. Melihat hal tersebut, jelaslah bahwa yang menjadi doa keselamatan di dalam Ladrang Wilujeng bukan hanya dari teks syair atau cakepan secara konvensional, namun juga dari kekuatan makna gendhing itu sendiri.

\section{Ladrang Éling-éling Laras Sléndro Pathet Manyura}

Gendhing ini merupakan gendhing yang umum tersebar di beberapa daerah di Jawa. Secara usia, gendhing ini tergolong dalam gendhing tua, namun hingga sekarang belum bisa dipastikan sejarahnya. Menurut Rusdiyantoro (wawancara 3 Juli 2019), salah satu dosen jurusan karawitan di ISI Surakarta, Ladrang Éling-éling diasumsikan berasal dari rakyat, bukan ciptaan kalangan kerajaan atau keraton. Gendhing tersebut beredar di masyarakat, kemudian terjadi mobilitas horisontal di mana gendhing tersebut beredar kepada masyarakat, sekaligus mobilitas vertikal ke kalangan keraton. Gendhing tersebut diadopsi oleh kalangan keraton menjadi Gendhing Éling-éling Suralaya, Éling-éling Badranaya, atau Éling-éling Kasmaran. Hal tersebut diasumsikan karena tidak adanya bukti secara tekstual adanya sejarah Ladrang Éling-éling yang pasti.

Dalam pandangan ketua RT setempat, Sukimin, Ladrang Éling-éling diartikan sebagai salah satu media untuk mengingat, dalam hal ini kepada siapa saja terutama pada Tuhan Yang Maha Esa. Sebab, dalam keadaan sadar, manusia lebih peka terhadap makhluk-makhluk lain, sedangkan dalam keadaan tidak sadar atau setengah sadar, manusia akan mudah sekali mengalami trance. Dalam hal ini, dapat diartikan bahwa Éling-éling sebenarnya merupakan contoh atau teladan bagi seseorang untuk selalu ingat. Senada dengan penuturan juru kunci pundhèn, Samiyun, bahwa Ladrang Éling-éling dijadikan sebagai gendhing wajib supaya masyarakat selalu ingat terhadap Sang Pencipta, cikal bakal dusun, dan jasa leluhur. Harapannya, tradisi bersih dusun Dalungan dapat tetap dilaksanakan sesuai waktu yang telah ditentukan.

Hal lain disampaikan oleh Sumali (wawancara 12 Juli 2019), salah satu tokoh seniman di Dusun Dalungan, bahwa Ladrang Éling-éling satu dekade yang lalu merupakan bagian inggah dari Gendhing Gambirsawit, namun sudah tidak lagi dilakukan selama sepuluh tahun terakhir ini. Hal tersebut dikarenakan beberapa faktor, antara lain 
kurangnya pengetahuan pengrawit mengenai gendhing-gendhing yang dimaksud, sehingga lambat laun tradisi tersebut hanya berhenti pada judul gendhing saja.

Ladrang Éling-éling dalam upacara bersih dusun Dalungan disajikan dengan Gérongan Ladrang Éling-éling Sléndro Pathet Manyura, dengan teks dan terjemahan bebas sebagai berikut.

Nenggih satriya gung para pandhawa, oncat saking praja Astina kèh pra janma, Béla sungkawa, Adhuh déwa, Ayomana p'ra Pandhawa.Kesatria Pandhawa, meninggalkan kerajaan Astina, semua orang merasa sedih atau turut berbela sungkawa, memohon kepada dewa untuk selalu melindungi para Pandhawa.

Nenggih satriya gung para pandhawa, oncat saking praja Astina kèh pra janma, Béla sungkawa, Adhuh déwa, Ayomana p'ra Pandhawa.

Kesatria Pandhawa, meninggalkan kerajaan Astina, semua orang merasa sedih atau turut berbela sungkawa, memohon kepada dewa untuk selalu melindungi para Pandhawa.

Tabel 2. Gérongan Ladrang Éling-éling Sléndro Pathet Mnayura

Makna teks musikal di atas mengingatkan kepada sesama manusia agar selalu ingat kepada Tuhannya. Apabila manusia membuat kesalahan, maka ia harus berani menanggung akibatnya. Seperti halnya sedikit kesalahan seorang raja yang dapat membuat seluruh rakyat menderita. Dalam hal ini, manusia janganlah sampai menentang apapun yang sudah diatur oleh Tuhan, akan tetapi bila mendapat tantangan, maka perlu dihadapi.

Teks atau cakepan pada Gérongan Ladrang Éling-éling Laras Sléndro Pathet Manyura seakan mengajak kita untuk kembali kepada Tuhan Yang Maha Esa. Éling berarti ingat, dalam suasana suka maupun duka, kita diajak untuk selalu ingat kepada sang pencipta. Gendhing tersebut mengingatkan masyarakat Dalungan untuk selalu mengingat jasa-jasa serta mendoakan orang tua, nenek moyang, maupun pahlawan yang telah tiada. Dalam teks tersebut, terdapat pengajaran bahwa kehidupan itu sifatnya sementara, dan semua akan kembali kepada Sang Pencipta. Gendhing ini juga mengingatkan kepada kehidupan yang kekal, yaitu kematian. Melalui gendhing tersebut, masyarakat Dalungan mengharapkan perlindungan kepada Tuhan Yang Maha Esa dari mala petaka, serta senantiasa selalu mendekatkan diri kepada Tuhan Sang Pencipta Alam.

\section{Gendhing Gambirsawit Laras Sléndro Pathet Sanga}

Gambirsawit merupakan salah satu bentuk gendhing yang umum dimainkan di Jawa. Menurut Babad Tanah Jawa, Gendhing Gambirsawit diciptakan pada masa kerajaan Pajang (1668-1687) oleh seorang empu; akan tetapi dalam Serat Centhini, dijelaskan bahwa gendhing ini diciptakan pada pemerintahan Pakubuwono IV pada tahun 1891. Lain halnya dengan Wedapradangga yang menjelaskan bahwa Gendhing Gambirsawit diciptakan olah Kanjeng Sunan Kalijaga (lihat Prajapangrawit 1990).

Pada masa itu, diceritakan bahwa Kanjeng Sunan Kalijaga membuat gendhing Laras Sléndro Pathet Sanga yang diambil dari lagu pathetan sanga, yaitu Ladrang Gonjang-Ganjing dan Gambirsawit Kethuk 2 Kerep Inggah 4. Kanjeng Sunan Kalijaga menciptakan kedua gendhing tersebut dengan maksud sebagai perlambang. Dalam hati orang Jawa yang baru saja memeluk Agama Islam, "rasanya tidak karuan" seperti bumi yang sedang gonjang-ganjing (terguncang). Akan tetapi, setelah dirasakan lama kelamaan, ternyata ajarannya hampir sama dengan agama yang dianut sebelumnya (Buddha). Cara beribadahnya berbeda, namun isiannya sama, yaitu menyembah TuhanAllah. Setelah benar-benar mantap memeluk Agama Islam, Kanjeng Sunan Kalijaga merasa padhang (terang 
jalan hidupnya), marem (puas dan mantap hatinya), dan gembira (bergembira karena menemukan dua hal yang cocok), sehingga dari itu terciptalah gendhing kedua, yaitu Gendhing Gambirsawit Kethuk 2 Kerep Inggah 4.

Gendhing Gambirsawit oleh orang Jawa dijadikan sebagai pelukisan atas kehidupan masyarakat yang sudah tenang, tentram, makmur, dan tidak ada lagi kekacauan atas kekuasaan bahkan agama. Gambir diartikan sebagai 'bunga', sedangkan sawit berarti 'kembar' atau 'sepasang'. Semua yang sifatnya sepasang merupakan "sawit". Hal ini sangat relevan dengan tempat yang dijadikan sebagai pusat upacara bersih dusun Dalungan, yang mana terdapat artefak berupa yoni. Yoni biasanya dipasangkan dengan lingga, sedangkan pada masa Neolitikum, lingga dan yoni diartikan sepasang simbol kesuburan antara laki-laki dan perempuan.

Berkaitan dengan mitos yang ada, artefak tersebut merupakan cikal bakal dusun, atau pusat nilai magis dan spiritual di dusun tersebut. Maka sangatlah relevan apabila Gendhing Gambirsawit Kethuk 2 Kerep inggah 4 laras Sléndro Sanga dijadikan sebagai salah satu gendhing wajib pada upacara bersih dusun Dalungan, mengingat sebagai salah satu persembahan hormat kepada cikal bakal dusun, ia secara oral memiliki nilai magis yang sangat tinggi. Hal tersebut diperkuat dengan adanya ceritacerita tentang dhanyang dan pundhèn.

Seperti yang telah dijelaskan dalam Bothekan II oleh Rahayu Supanggah, bahwa secara ukuran, Gendhing Gambirsawit termasuk dalam golongan gendhing tengahan karena memiliki bentuk kethuk 2 kerep inggah 4. Gendhing Gambirsawit merupakan gendhing tua yang usianya kurang lebih 200 tahun. Secara musikal, Gendhing Gambirsawit memiliki garap yang bagus dan mudah untuk dimainkan, sehingga popularitas gendhing ini cukup baik di kalangan karawitan di Surakarta. Menurut Sumali, dalam upacara bersih dusun Dalungan sepuluh tahun yang lalu, Gendhing Gambirsawit masih disajikan dengan mengambil bagian kibar-nya saja, karena kebutuhan dalam mengiringi tari tayub. Namun setelah satu dekade terakhir, hal terebut mulai luntur dan berubah dengan menyajikan gendhing secara utuh. Seni dan tradisi bersifat dinamis dan dapat berubah sesuai kondisi lingkungan, media, ekonomi dan masih banyak faktor lainnya. Gendhing Gambirsawit Kethuk 2 Kerep Inggah 4 Laras Slendro Pathet Sanga yang dimainkan dalam upacara bersih dusun Dalungan menggunakan tembang Asmarandana dengan cakepan sebagai berikut.

Aja turu soré kaki, ana Déwa nglalang jagad, nyangking bokor kencanané, isiné donga tetulak, sandhang kalawan pangan, yaiku bagéyanipun, wong melèk sabar narima.

Jangan tidur sore hari, ada Dewa sedang berkeliling dunia, menjinjing bejana emas, isinya doa tolak bala, pakaian juga makanan, pada bagian tersebut, disaat sedang sadar harus senantiasa bersabar dan menerima kenyataan.

Tabel 3. Cakepan tembang Asmarandana

Teks musikal tersebut merupakan pengajaran tentang kepribadian orang Jawa, jika seseorang mempunyai cita-cita yang luhur dan mulia jangan hanya bekerja, namun juga harus mengimbanginya dengan cara-cara tertentu. Sesuai dengan tradisi orang Jawa yang memiliki filosofi yang mendalam, yaitu bisa menahan lapar dan kantuk, jatuhnya wahyu biasanya mengitari orang-orang seperti itu.

Kalimat aja turu soré kaki merupakan kalimat peringatanyang berartitidak boleh tidur pada sore hari. Secara mitos, waktu sore merupakan pergantian waktu dari siang ke malam, dari terang ke gelap. Pada masa itulah pergantian alam dimulai. Kata turu atau tidur dalam hal ini bukan hanya sekedar berarti memejamkan mata, namun juga wujud absennya kesadaran. Penggalan cakepan atau teks tersebut berkaitan erat dengan upacara bersih dusun Dalungan yang dilaksanakan pada sore hari dan dilanjutkan pada malam hari. Melalui 
Gendhing Gambir Sawit, masyarakat Dalungan dihimbau untuk tidak tidur di sore hari dan dianjurkan untuk memperbanyak aktivitas religius di sore hari.

Cakepan lain yang berbunyi ana déwa nglanglang jagad, nyangking bokor kencanané, isiné donga tetulak. Teks tersebut merupakan metafora, bahwa kesadaran tersebut hadir di dalam diri manusia. Kesadaran ini ibarat bokor atau bejana yang terbuat dari emas, berisi air bunga. Kesadaran tersebut tentunya harus diisi dengan hal-hal yang bermanfaat dan gembira, utamanya doa-doa keselamatan atau penolak bala. Teks selanjutnya berbunyi sandhang kalawan pangan, yaiku bagéyanipun, wong melèk sabar narima. Dalam hal ini dianalisis bahwa rizki itu datang kepada orangorang yang bersabar, bersyukur, dan orang-orang yang paham akan balas budi (wawancara Sumali, 12 Juli 2019).

Peran Gendhing Gambirsawit dalam upacara bersih dusun Dalungan sangatlah penting. Menurut Samiyun, gendhing tersebut merupakan gendhing yang paling disukai oleh dhanyang yang ada di pundhèn. Selain memiliki filosofi gendhing yang menarik, mitos gendhing Gambirsawit didasari kaitannya dengan dhanyang atau cikal bakal dusun, sehingga sebagian besar masyarakat Dalungan akan patuh terhadap apa yang sudah menjadi tradisi sebelumnya, hingga kebiasaan tersebut berubah menjadi mitos yang hingga kini diyakini oleh masyarakat Dalungan.

\section{Penutup}

Mitos gendhing dalam upacara bersih dusun Dalungan merupakan salah satu bentuk tradisi cegah dhusun yang dilakukan oleh masyarakat Kecamatan Kebakkramat, khususnya Dusun Dalungan. Kehadiran ritual bersih dusun Dalungan sangat erat kaitannya dengan kehidupan sosial budaya masyarakat pendukungnya, yaitu budaya sosial melalui aktivitas doa dan pesta kenduri bersama, bergembira dengan menikmati kesenian tayub, dan mempelajari gendhing-gendhing wajib yang disajikan.
Dalam alam pikir orang Jawa, sebuah tradisi ritual perlu dijaga setidaknya secara lisan. Dalam hal ini diharapkan sebuah tradisi yang hingga sekarang membangun Jawa tidak hilang tanpa membekas suara. Hingga mitos-mitos lain di Jawa juga disampaikan sebagai acuan dan relasi yang dibangun. Adanya mitos gendhing pada upacara bersih dusun Dalungan hingga sekarang masih bertahan dan diyakini masyarakat setempat sebagai sesuatu yang sakral. Elemen-elemen lain yang juga mempengaruhi kesakralan ritual adalah sajian tayub yang diiringi tiga gendhing wajib, yaitu Ladrang Wilujeng Laras Sléndro Pathet Manyura, Ladrang Éling-éling Laras Sléndro Pathet Manyura, dan Gendhing Gambirsawit Kethuk 2 Kerep inggah 4 Laras Sléndro Pathet Sanga. Gendhing-gendhing tersebut merupakan gendhing yang wajib disajikan ketika bersih dusun berlangsung.

Pertunjukan karawitan dari berbagai kelompok sering ditampilkan dalam upacara bersih dusun Dalungan. Dengan hal ini, garap gendhing bisa saja dikemas dengan cara berbeda pula, karena masing-masing pengrawit biasanya memiliki gaya. Jadi, mitos tersebut tidak terbangun dari garap gendhing yang dipakai, melainkan dari fungsi dan makna dari ketiga gendhing tersebut.

Sajian gendhing wajib dalam upacara bersih dusun Dalungan sebagai prosesi ritual memiliki beberapa fungsi, bentuk dan makna. Fungsi tersebut dibagi menjadi dua, yaitu fungsi sosial dan fungsi hubungan antara layanan dan seni. Makna yang tergandung dalam ketiga gendhing wajib tersebut memiliki makna yang luas.

Penulis menyadari bahwa mitos gendhing dalam upacara bersih dusun Dalungan memiliki potensi menarik untuk dilestarikan sebagai aset kebudayaan daerah, khususnya Kabupaten Karanganyar. Demi menjaga kesenian tersebut, penulis berharap ada kerjasama yang baik antara masyarakat dengan aparatur pemerintah derah. Upacara bersih dusun Dalungan telah ditetapkan oleh Pemerintah Kabupaten Karanganyar sebagai potensi cagar budaya yang ada di Kabupaten Karanganyar. 


\section{DAFTAR PUSTAKA}

Anderson, Benedict R. O'. 2008. Mitologi Dan

Toleransi Orang Jawa. Yogyakarta: Jejak.

Barthes, Roland. 1981. Mithologies. New York: Granada Publising.

Danandjaya, J. 1986. Folklor Indonesia: Ilmu Gosip, Dongeng, Dan Lain-Lain. Jakarta: Pustaka Grafitipers.

Hastanto, Sri. 2009. Konsep Pathet Dalam Karawitan Jawa. Surakarta: Program Pascasarjana Bekerja Sama Dengan ISI Press Surakarta.

Iswidayanti, Sri. 2007. "Fungsi Mitos Dalam Kehidupan Sosial Budaya Masyarakart Pendukungnya (The Function of Myth in Social Cultural Life of Its Supporting Community)." Harmonia: Journal of Arts Research and Education 8(2):18084.

Kasanova, Ria and Sri Widjajanti. 2018. "Mitos Dan Kontramitos Dalam Novel Mantra Penjinak Ular Karya Kuntowijoyo." Deiksis: Jurnal Pendidikan Bahasa Dan Sastra Indonesia 5(2):102-11.

Kiswanto, Rr. Paramitha Dyah Fitriasari, and Timbul Haryono. 2019. "Transformasi Multipel Dalam Pengembangan Seni Kuda Kepang." Dance and Theatre Review 2(1):1-16.

Malinowski, Bronislaw. 1979. "The Role of Magic and Religion." Reader in Comparative Religion 86.

Martopengrawit. 1975. Pengetahuan Karawitan Jilid 1. Surakarta: ASKI.

Nicolas, Arsenio. 2019. "Traditional Music and Contemporary Trends: Music in Asean
Communities." Sorai: Jurnal Pengkajian

Dan Penciptaan Musik 12(1):54-56.

Prajapangrawit, R. Ng. 1990. "Serat Sujarah Utawi Riwayating Gamelan Wedhapradangga." in Gothek: Jilid I-VI. Surakarta: STSI Surakarta dengan Fort Foundation.

Supanggah, Rahayu. 2007. Bothekan Karawitan II. Surakarta: ISI Press.

Susanto, S. P. Harry. 1987. Mitos Menurut Pemikiran Mircea Eliade. Yogyakarta: Kanisius.

Uniawati. 2012. "Takhayul Seputar Kehamilan Dan Kelahiran Dalam Pandangan Orang Labuan Bajo: Tinjauan Antropologi Sastra." Patanjala 4(1):1-13.

Wahyudi, Joko. 2018. "Pengaruh Karawitan Gaya Sragen Pada Selera Masyarakat Kebakkramat." Sorai: Jurnal Pengkajian Dan Penciptaan Musik 11(2).

Wibowo, Yuliyanto Tri. 2018. "Kebertahanan Gending-Gending Baku Dalam Upacara Ritual Bersih Desa Di Dukuh Dalungan, Desa Macanan, Kecamatan Kebakkramat." Program Studi S-1 Seni Karawitan Fakultas Seni Pertunjukan Institut Seni Indonesia Surakarta.

Yulia, Desma and Afrinel Okwita. 2017. "Sejarah Perkembangan Mitos Sebagai Kehidupan Sosial Masyarakat Sugi Kecamatan Moro Kabupaten Karimun Pada Tahun 1998-2015.” Jurnal Dimensi 6(3):38092.

\section{DAFTAR NARASUMBER}

Marto Samiyun (84 tahun), sesepuh atau juru kunci pundhen. Dalungan, Macanan, Kebakkramat, Karanganyar. 
Rusdiyantoro, S.Kar., M.Sn (61 tahun), dosen karawitan ISI Surakarta. Benowo, Ngringo, Jaten, Karanganyar.

Sukimin (65 tahun), ketua RT Dusun Dalungan. Dalungan, Macanan, Kebakkramat, Karanganyar.
Sukino (54 tahun), tokoh masyarakat (pelaku tradisi). Dalungan, Macanan, Kebakkramat, Karanganyar.

Sumali (55 tahun), seniman, pematung, pelukis (tokoh masyarakat). Dalungan, Macanan, Kebakkramat, Karanganyar. 